Journal of Agrometeorology 23 (4) : 423-427 (December 2021) : https://doi.org/10.54386/jam.v23i4.147

\title{
Variability of potential evapotranspiration and moisture conditions in Srikakulam district of Andhra Pradesh
}

\author{
SRAVANI ALANKA ${ }^{1}$ and LAKSHMANA RAO.VENNAPU ${ }^{2 *}$ \\ ${ }^{1}$ Meteorological Centre, India Meteorological Department, Hyderabad, India. \\ ${ }^{2}$ Dept. of Meteorology and Oceanography, Andhra University, Visakhapatnam, India \\ *Corresponding author email : lakshman.met@gmail.com
}

\begin{abstract}
In the present study, evapotranspiration and moisture adequate index for the 37 mandals of the Srikakulam district for the year 2018 has been estimated. The PET values were very high in the summer season of all the mandals than in the other seasons. The normal PET values were lower than that of the actual PET values showing location specific and better estimation characteristics. This estimation of location-specific PET can be helpful for the drought classification and water management planning within the district. Moisture adequate index of all the mandals has indicated that the district as a whole has a humid/temperate climate; but within the district, mandals report different conditions. This makes it a more relevant tool for drought, microclimatic classification and annual water planning for sustainable agriculture.
\end{abstract}

Keywords: Evaporation, moisture adequate index, humid, microclimate.

Under the exacting conditions of climate change and unpredictable weather conditions following uneven rainfall events (IPCC, 2008) the availability of waterlimited not only for domestic use but also for agricultural and non-agricultural practices. Evaporation is a major component of the hydrologic cycle as water balance, water resources planning and management, crop management and irrigation scheduling (Rao et al., 2012). Some studies have documented (Mallick et al., 2007; Bhattacharya et al., 2010) the spatial variability of Evapotranspiration over crops in India. Rathore and Biswas (1991) prepared the climatological maps of daily evaporation and weekly evaporation those maps give a good idea about the spatial and temporal variation of evaporation over India. The likely causative meteorological parameters for such changes are identified. Future warming seems likely to lead to increased potential evapotranspiration over India, (Goroshi et. al., 2017) exhibiting potential evapotranspiration season-wise increasing trend during northeast winter monsoon $\left(\mathrm{m}=0.156 \mathrm{~mm}\right.$ season $^{-1}$ year $\left.{ }^{-1}\right)$ and pre-monsoon $\left(\mathrm{m}=0.068 \mathrm{~mm} \mathrm{season}^{-1}\right.$ year $\left.^{-1}\right)$ periods in India. The main objective of the study was to estimate PET using FAO -56-Penmann Monteith method at mandal (within district) level which may effectively help to the drought and water management and irrigation scheduling locations wise.

\section{MATERIALS AND METHODS}

\section{Study area}

Srikakulam is the coastal district of the Indian state of Andhra Pradesh. It is within the geographic coordinates of $18^{\circ}-20^{\prime}$ and $19^{\circ}-10^{\prime} \mathrm{N}$ latitude and $83^{\circ}-50^{\prime}$ and $84^{\circ}-50^{\prime}$ E longitude with an elevation of $10 \mathrm{~m}$ AMSL. It is one of the districts in the line of Eastern Ghats. It receives an average annual rainfall of $1100 \mathrm{~mm}$ of which about 60 per cent received in the monsoon season, 25 per cent in post-monsoon season and the rest of 15 per cent in winter and pre-monsoon seasons.

Weather parameters viz., maximum temperature, minimum temperature, maximum relative humidity, minimum relative humidity, wind speed, pressure have been collected from 115 AWS stations installed in 36 mandals for the Andhra Pradesh State Development Planning Society (APSDPS), AP in the district of Srikakulam for the year 2018. The required climatological data (19812015) has been collected from the Indian Meteorological Department (IMD). The geo-coordinates for the respective AWS Stations have been used for the calculation of the 
Table 1: Equations used to derive various parameters.

\begin{tabular}{|c|c|c|c|}
\hline $\begin{array}{l}\text { S. } \\
\text { No. }\end{array}$ & Parameters & Expressions & Units \\
\hline 1. & $\begin{array}{l}\text { Slope of the saturation } \\
\text { vapour pressure curve }\end{array}$ & $\begin{array}{l}\Delta=0.618 \exp ((17.27 \mathrm{~T}) /(\mathrm{T}+237.3)) \\
{[\mathrm{T}+237.3] 2}\end{array}$ & $\mathrm{KPaeC}^{-1}$ \\
\hline 2. & $\begin{array}{l}\text { Mean saturated vapour } \\
\text { pressure }\end{array}$ & $\mathrm{e}_{\mathrm{s}}=\mathrm{e}_{0} \operatorname{Tmax}(\operatorname{mean})+\mathrm{e}_{0} \operatorname{Tmin}($ mean $)$ & $\mathrm{KPa}$ \\
\hline 3. & $\begin{array}{l}\text { Saturated vapour pressure } \\
\text { at temp ' } \mathrm{T} \text { ' }\end{array}$ & $\mathrm{e}_{0}(\mathrm{~T})=0.6108 \exp ((17.27 \mathrm{~T}) /(\mathrm{T}+237.3))$ & $\mathrm{KPa}$ \\
\hline 4. & Actual vapour pressure & $\left.\mathrm{e}_{\mathrm{a}}=\left[\mathrm{e}_{0}(\operatorname{Tmin}) \times(\mathrm{RHmax} / 100)\right]+\mathrm{e}_{0}(\operatorname{Tmax}) \times(\mathrm{RHmin} / 100)\right] 2$ & $\mathrm{~K} \mathrm{~Pa}$ \\
\hline 5. & Vapour pressure deficit & $\left(e_{s}-e_{a}\right)$ & $\mathrm{K} \mathrm{Pa}$ \\
\hline 6. & Clear sky solar radiation & $\begin{array}{l}\mathrm{RS}=(0.75 \times 2 \times 10-5 \times \mathrm{Z}) \mathrm{RSO} \\
\text { Where } \mathrm{Z}=\text { Altitude of location, } \\
\qquad \mathrm{RSO}=\text { Extra-terrestrial radiation }\end{array}$ & $\mu \mathrm{Jm}-2 \mathrm{~d}^{-1}$ \\
\hline 9. & Net long wave radiation & $\mathrm{R}_{\mathrm{nl}}=\alpha\{[(\mathrm{TmaxK}) 4-(\mathrm{TminK}) 4] \div 2\} \times(0.34-0.14 \sqrt{e} \alpha) \times[1.35(\mathrm{RS} / \mathrm{RO})-0.35]$ & $\mu \mathrm{Jm}-2 \mathrm{~d}^{-1}$ \\
\hline 10. & Net radiation(Rn) & $\mathrm{Rn}=\mathrm{Rns}-\mathrm{Rnl}$ & $\mu \mathrm{Jm}-2 \mathrm{~d}^{-1}$ \\
\hline 11. & Wind speed at height ' $Z$ ' $\mathrm{cm}$ & $\mu_{2}=\underset{\operatorname{Ln}(67.8 Z-5.42)}{4.87} \mu_{z}$ & $\mathrm{Ms}^{-1}$ \\
\hline 12. & Psychrometric constant & $\gamma=0.655 \times 10-3 \times P$ & $\mathrm{~K} \mathrm{~Pa} 0 \mathrm{C}^{-1}$ \\
\hline 13. & ETo & Reference evapotranspiration & $\mathrm{mm} \mathrm{day}^{-1}$ \\
\hline 14. & $\mathrm{G}$ & Soil heat flux density & M J m-2 day ${ }^{-1}$ \\
\hline
\end{tabular}

sunshine hours, solar radiation using empirical equations (Table 1). The monthly and seasonal values of PET and MDI for Srikakulam have been presented. The followings methods have been used to calculate the PET and MDI for the determination of PET from meteorological data. According to Rambabu and Bapuji Rao (1999) and Rao et al., (2012), potential evapotranspiration estimated with the FAO-56 Penman-Monteith method was the effective method when compared to the other estimated methods in Indian conditions. For the estimation of PET, the FAO Penman-Monteith Model with the following formulae was used:

$$
E T_{o}=\frac{0.408 \Delta\left(R_{n}-G\right)+\gamma \frac{900}{T+273} u_{2}\left(e_{s}-e_{a}\right)}{\Delta+\gamma\left(1+0.34 u_{2}\right)}
$$

Where expressions considered in FAO PM Model

The following formula (Thornthwaite) was used to calculate the MDI.

$$
\mathrm{MDI}=(\mathrm{P}-\mathrm{PET}) / \mathrm{PET} \times 100
$$

$\mathrm{P}=$ Precipitation $($ in $\mathrm{mm})$;

PET $=$ Potentialevapotranspiration $($ in $\mathrm{mm})$

The inverse distance weighted interpolation technique was also used to explore the spatial analysis of PET and MDI with the help of Quantum GIS.

\section{RESULTS AND DISCUSSION}

The seasonal weekly average PET values at each mandal of the district Srikakulam are presented in Table 2. In the winter season, the PET values ranged from 10.7 to $31.7 \mathrm{~mm}$ across the mandals. In the winter months, due to low temperatures, the values of PET were also low being a function of temperatures. The SMWs from 40 to 52 (post-monsoon) season and SMWs of 1-8 (winter) season has shown the lowest value of PET, particularly for the Srikakulam district. In the post-monsoon season, the PET values range from 6.9 in Pathapatanam to 35.1 $\mathrm{mm}$ in Tekkali. Srikakulam district is the most vulnerable with the advent of cyclonic storms in the post-monsoon season. The path of the cyclone may hit the district or cross near the Orissa coast causing very heavy rainfall 
Table 2 : Average PET $\left(\mathrm{mm} \mathrm{day}^{-1}\right)$ of the year 2018 for the mandals of the Srikakulam District

\begin{tabular}{|c|c|c|c|c|}
\hline \multicolumn{5}{|c|}{ Average potential evapotranspiration in $\left(\mathrm{mm} \mathrm{day}^{-1}\right)$} \\
\hline Mandal name & 1-8 SMWs & 9-22 SMWs & 23-39 SMWs & 40-52 SMWs \\
\hline Amadalavalasa & 28.6 & 78.1 & 36.4 & 20.7 \\
\hline Bhamini & 28.3 & 112.2 & 38.7 & 23.1 \\
\hline Burja & 22.7 & 70.0 & 38.3 & 25.0 \\
\hline Etcherla & 28.2 & 78.3 & 31.7 & 16.3 \\
\hline Ganguvarisigadam & 32.4 & 71.8 & 32.3 & 25.2 \\
\hline Gara & 26.5 & 67.9 & 31.4 & 19.8 \\
\hline Hiramandalam & 24.7 & 29.4 & 9.5 & 24.7 \\
\hline Ichchapuram & 23.0 & 80.2 & 48.4 & 20.6 \\
\hline Jalumuru & 31.7 & 84.3 & 45.9 & 21.7 \\
\hline Kanchili & 30.1 & 73.0 & 29.2 & 24.5 \\
\hline Kaviti & 10.7 & 45.4 & 26.0 & 16.2 \\
\hline Kottabommili & 24.6 & 74.6 & 34.4 & 19.4 \\
\hline Kotturu & 33.0 & 78.7 & 36.6 & 19.1 \\
\hline Laveru & 28.7 & 77.8 & 29.8 & 22.0 \\
\hline Mandasa & 27.1 & 76.2 & 37.0 & 23.5 \\
\hline Meliaputti & 19.7 & 34.8 & 40.0 & 19.0 \\
\hline Nandigam & 26.9 & 53.2 & 31.5 & 23.9 \\
\hline Narsannapeta & 31.4 & 100.8 & 34.0 & 18.7 \\
\hline Palakonda & 24.4 & 71.9 & 26.1 & 20.6 \\
\hline Palasa & 16.6 & 57.1 & 34.3 & 16.4 \\
\hline Pathapatnam & 21.4 & 54.7 & 27.0 & 6.9 \\
\hline Polaki & 27.4 & 63.9 & 30.6 & 22.7 \\
\hline Rajam & 28.9 & 34.8 & 25.3 & 19.9 \\
\hline Ranastalam & 18.9 & 28.0 & 20.3 & 14.7 \\
\hline Regidiamadalavala & 30.0 & 88.1 & 38.1 & 25.4 \\
\hline Santhabommali & 20.8 & 39.2 & 38.9 & 29.7 \\
\hline Santhakaviti & 21.7 & 66.8 & 28.0 & 13.9 \\
\hline Sarbujjili & 26.5 & 58.1 & 36.5 & 15.9 \\
\hline Seethampeta & 18.8 & 37.0 & 22.0 & 22.4 \\
\hline Sompeta & 14.7 & 35.1 & 30.2 & 15.5 \\
\hline Srikakulam & 25.5 & 63.1 & 28.9 & 21.2 \\
\hline Tekkau & 29.6 & 50.9 & 35.3 & 35.1 \\
\hline Vajrapukotturu & 27.6 & 56.9 & 19.6 & 16.3 \\
\hline Vangara & 22.9 & 76.5 & 31.4 & 17.3 \\
\hline Veeraghattam & 31.4 & 72.8 & 30.9 & 22.8 \\
\hline Average & 25.3 & 64.0 & 31.8 & 20.6 \\
\hline
\end{tabular}

which resulted in low evaporation. In the summer season, i.e. 9-22 SMWs, the PET values were higher ranged from $28.0-112.2 \mathrm{~mm}$. Bhamini mandal recorded a very high value $112.2 \mathrm{~mm}$ followed by Narasannapeta at 100.8 $\mathrm{mm}$. However, places like Ranastalam mandal recorded a minimum value of $28.0 \mathrm{~mm}$ followed by Hiramandalam (29.4). In the SW monsoon season, the PET values were ranged from $9.5 \mathrm{~mm}$ in Hiramandalam to $48.4 \mathrm{~mm}$ in Ichchapuram. The actual PET values for the year 2018 have been compared with the normal (1981-2010) PET value of the Srikakulam district as a whole (Fig. 1). Actual PET values during 1 to 8 SMWs exhibited slightly high values compared to the normal; the normal being $20.0 \mathrm{~mm} \mathrm{day}^{-1}$ and the actual value $25.0 \mathrm{~mm}^{-1} \mathrm{day}^{-1}$. However, for SMWs 9 to 22 , the normal value was $28.0 \mathrm{~mm} \mathrm{day}^{-1}$ as against the actual value of $65.0 \mathrm{~mm}$ day $^{-1}$. Such an enormous increase may be attributed due to increased warming. During 23 to 39 SMWs, the actual value of $30.0 \mathrm{~mm} \mathrm{day}^{-1}$ was $10.0 \mathrm{~mm}$ day $^{-1}$ higher than the normal value. It was only during the 40 to 52 SMWs, the actual value was less than the normal 


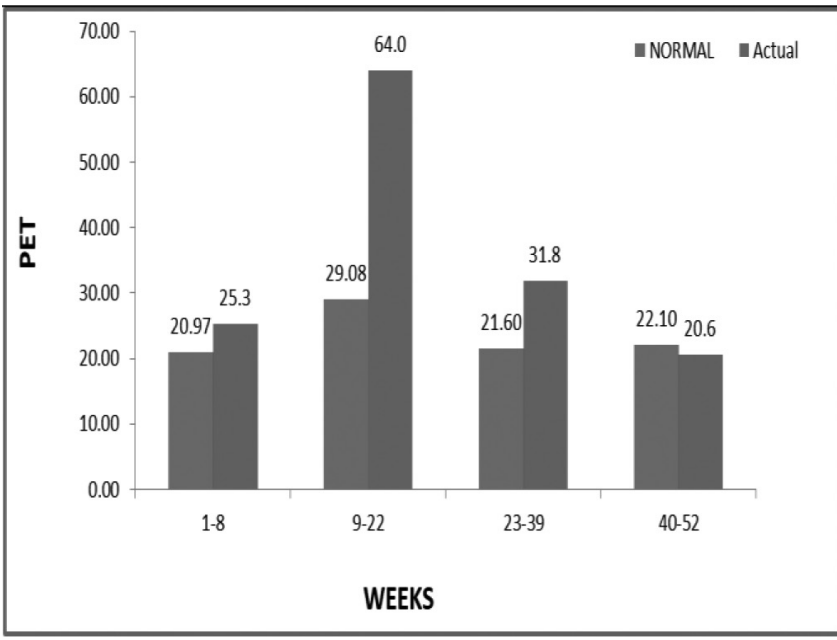

Fig. 1: Comparison between actual and normal PET of Srikakulam

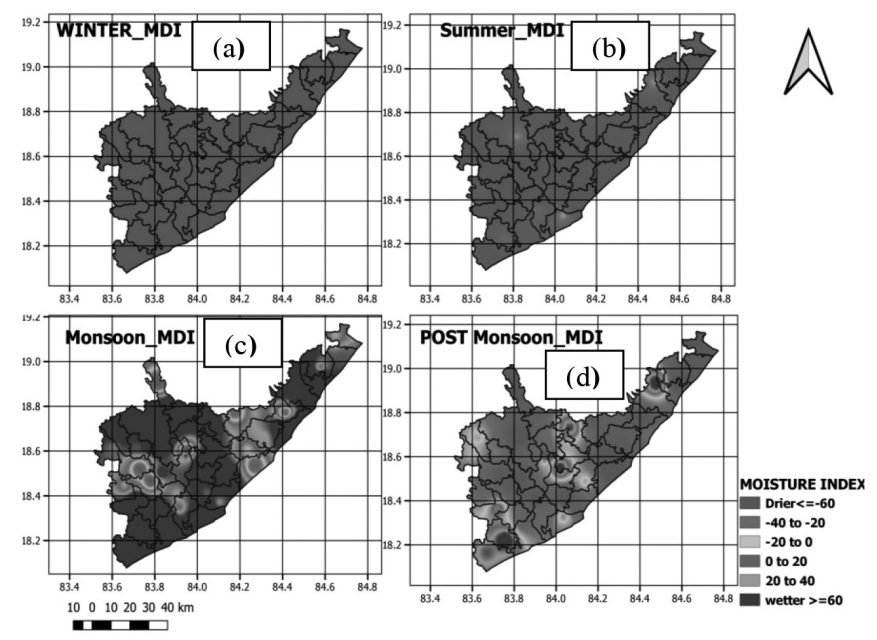

Fig. 3 (a-d): Seasonal spatial distribution of MDI

value. According to Subrahmanayam, (1982) most of the crops in India do not seem to have favourable conditions for growth below 40 per cent of MAI unless otherwise raised as irrigated crops. The seasonal PET of the Srikakulam district has been depicted in Fig. 2; mandals with high and low values in winter months were in the northernmost area and showed lower values $<250 \mathrm{~mm}$ (blue colour). The summer months have shown PET of $>1000 \mathrm{~mm}$ (red colour) in coastal and southern mandals. During the monsoon period, the PET values were in the 500-750 $\mathrm{mm}$ range for almost the entire district. Very few mandals reported 250-500 mm values of PET. The overall observations have shown the PET values predominately in the range of $250-500 \mathrm{~mm}$ in winters whereas monsoon season has shown a dominant value range of $500-750 \mathrm{~mm}$. The moisture adequate index had a value of -8.5 indicating the temperate climate of the Srikakulam district. Fig. 3 (a-

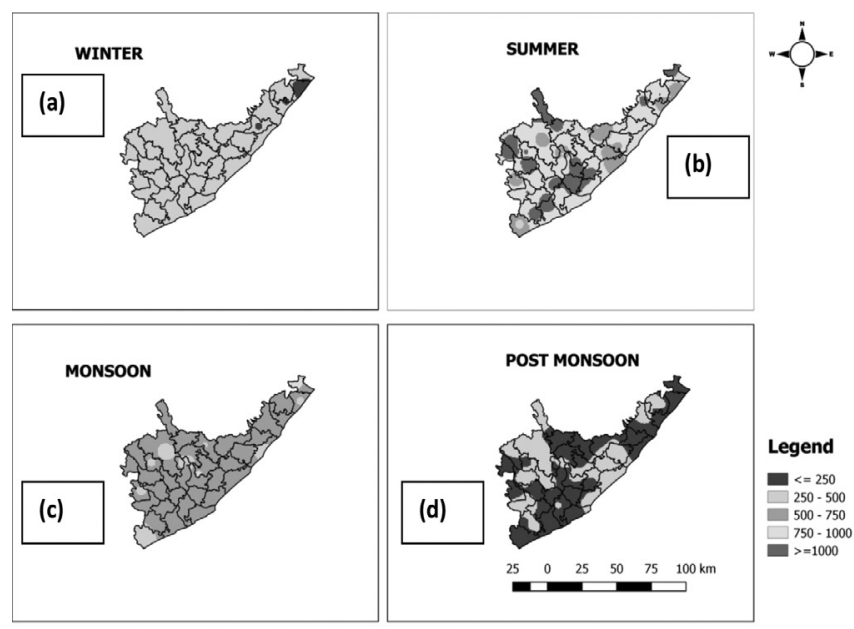

Fig.2 (a-d). Seasonal spatial distribution of PET
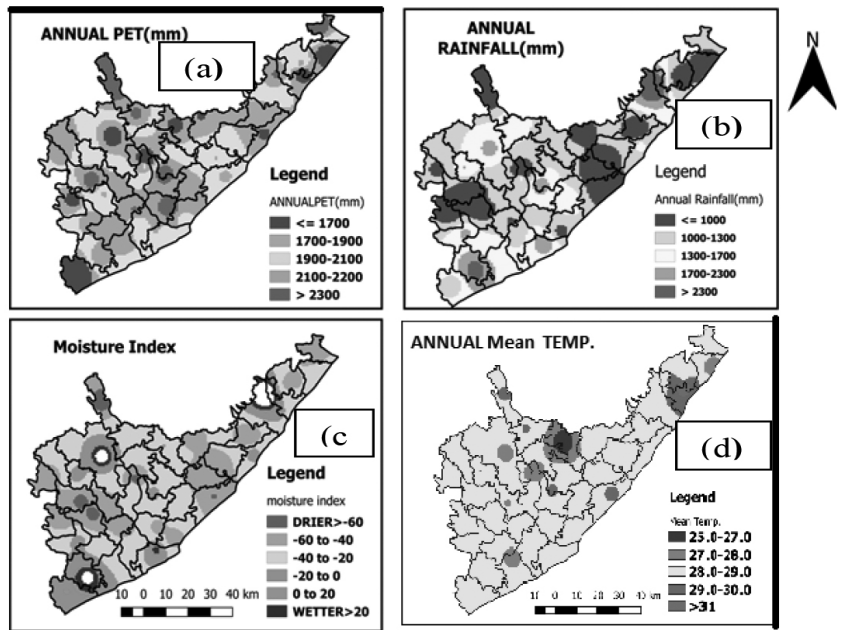

Fig. 4 (a-d): Spatial distribution of PET, annual rainfall, moisture index and mean temperature

d) depicted the seasonal spatial distribution of MDI for the year 2018 of Srikakulam district. The index values can provide valuable information on the liability to drought and therefore the climatic suitability of a region for agricultural or forest development (Gautam et. al., 2012). The natural pattern has been observed in many mandals in the Srikakulam district which was better during monsoon season lower moisture index value. This indicated that the season is more suitable for crops. The high value of MDI is high in winter and summer seasons, only allow short duration crops to complete their growth cycle. Fig. 4(ad)) depicted variations of PET, MDI, annual rainfall as well as annual mean temperature in each mandal. Sonali et al., (2016) too reported that the spatial and temporal variability was directly related to the changes in the PET. While looking at the mean annual temperature figures there were five spots of high annual mean temperature 
(marked in red) not suitable for crops like paddy; whereas there were four spots with low annual mean temperature (shown in blue), suitable for crops requiring more water and lower mean annual temperatures.

\section{CONCLUSIONS}

The seasonal PET values across mandals in the district have shown a certain trend. The PET values observed were higher in summer with the decrease in the monsoon season and a slight increase thereafter increases in the winter season. The rainy/monsoon season viz., 23 to 39 SMWs showed wide variations in PET values. Bhamini Mandal surrounded on three sides by Orissa state has shown wide variation. The coastal mandals viz., Santhabommali, Vajrakothuru, Sompeta, Kaviti and Ichapuram have shown less variation; whereas in the mandals located in the centre of the district, the variation was maximum. The high PET values indicated the increased water requirement for crops in the district. The results provided insight into the water requirement, management planning and drought classification in both the spatial and temporal scale for sustainable and resilient farming well within the district.

\section{ACKNOWLEDGEMENT}

The authors would like to express their sincere thanks and appreciation to the India Meteorological Department and APSDPS for providing data and valuable information. A special thanks to Dr.Vittal Murthy (Retd. Professor) from Andhra University for suggestions, constructive critiques and continued support.

Conflict of Interest Statement: The author(s) declare(s) that there is no conflict of interest.

Disclaimer: The contents, opinions, and views expressed in the research article published in the Journal of Agrometeorology are the views of the authors and do not necessarily reflect the views of the organizations they belong to.

Publisher's Note: The periodical remains neutral with regard to jurisdictional claims in published maps and institutional affiliations.

\section{REFRENCES}

Bhattacharya B K, Mallick K, Patel N K and Parihar J.S. (2010). Regional clear sky evapotranspiration over agricultural land using remote sensing data from Indian geostationary meteorological satellite; J. Hydrol. 387:65-80.

Gautam, S., Sumana Roy, S., Nain, A.S., Murty, N.S. Bisht, H., Vardhan H. and Panwar, R. (2012). Determination of Moisture Adequacy Index over Uttarakhand using GIS. J. Agrometeorol. 14 (Special Issue): 186-191.

Goroshi, S., Pradhan, R.,Singh, R.P., Singh, K.K. and Parihar, J.S., (2017). Trend analysis of evapotranspiration over India: Observed from long-term satellite measurements. J. Earth Syst. Sci.:126, Article No.113.

Mallick K, Bhattacharya, B. K., Chaurasia, S., Dutta S., Nigam, R., Mukherjee, J., Banerjee S., Kar, G., Rao, V. U. M. and Gadgil, A. S., (2007). Evapotranspiration using MODIS dataand limited ground observations over selected agro ecosystems in India. Int. J. Remote Sens. 28: 2091-2110.

Sonali, P., Kumar, D.N. (2016). Spatio-temporal variability of temperature and potential evapotranspiration over India" J. Water Clim. Change, 7(4): 810-822.

Rambabu, A. and Rao, B.B. (1999). Evaluation and calibration of some potential evapotranspiration estimating methods" J. Agrometeorol., 1(2): $155-162$.

Rao, B. B., Sandeep,V. M., Rao,V.U.M. and Venkateswarlu, B. (2012). Potential Evapotranspiration estimation for Indian conditions: Improving accuracy through calibration coefficients", Tech. Bull. No 1/2012. All India Co-ordinated Research Project on Agrometeorology, ICARCRIDA, Hyderabad, p60.

Rathore, L.S. and Biswas, B.C. (1991). Evaporation Maps of India" Agrimet Monograph No. 13, India Meteorological Department, Pune.

Subrahmanyam, V.P. (1982). "Water balance and its Applications" Andhra University Press. p102.

Thornthwaite, C.W. and Mather, J.R. (1955). Water Balance. Publ. In dim., Vol. VIII.1955 No. 1. 